\title{
Description of Lutzomyia (Evandromyia) sipani, a New Species of Sand Fly (Diptera: Psychodidae) from Loreto Department, Peru
}

\author{
Roberto Fernandez, Faustino Carbajal, Bruce Alexander, James T Need
}

NAMRID-Unit 3800, American Embassy, APO AA34031, U.S.A.

Lutzomyia sipani n.sp. is described from males collected in Loreto Department, Peru. The new species belongs to the subgenus Evandromyia Mangabeira and confirms the presence of this group in Peru.

Key words: Lutzomyia (Evandromyia) sipani n.sp. - Phlebotominae - sand flies - Loreto Department - Peru

The subgenus Evandromyia was described by Mangabeira in 1941, with Flebotomus infraspinosus (= Lutzomyia infraspinosa) designated as the type species. Young and Arias (1977) recognized nine species within the subgenus, which they divided into the series infraspinosa and monstruosa, containing seven and two species respectively. They believed the center of distribution of the group to be the Amazon basin, a region from which all of the described species except $L$ teratodes (Martin et al. 1964) have been recorded (Young \& Duncan 1993). The geographical distribution of the group extends from Colombia to Paraguay, including Venezuela, French Guiana, Surinam and Brazil. No Evandromyia species were however included in the list of Peruvian sand flies compiled by Llanos (1983). The first record of the subgenus in Peru was made by Young et al. (1985), who collected a female specimen in a flight trap in the Tambopata reserve in southeastern Peru and noted that its spermathecae were similar to those of $L$. (Evandromyia) infraspinosa. Confirmation of the specific identification was not possible since no males of this species were collected.

No further records of Evandromyia species were made from Peru until the present study, when two more species were collected in Loreto Department, in the northeast of the country. $L$

This research was supported by the Naval Medical Research and Development Command, NNMC, Bethesda, MD, Work Unit No. $61102 \mathrm{~A}$ 3M161102.B513.AK.1510. The opinions and assertions contained herein are private ones of the authors and are not to be construed as official or reflecting the views of the Department of the Navy or the Peruvian Government.

Received 2 August 1993

Accepted 17 December 1994
(Evandromyia) cerqueirai (Causey \& Damasceno 1945) was recorded for the first time in Peru and a new species was collected, a description of which follows. All measurements are in $\mathrm{mm}$.

\section{Lutzomyia (Evandromyia) sipani n.sp}

Femández, Carbajal, Alexander \& Need

Male Holotype: (Fig.). Color generally dark, with pleurae somewhat lighter than rest of the body. Distance from base of eyes to vertex 0.210 , head width 0.240 . Interocular distance 0.114 . Length of clypeus 0.084 . Cibarium toothless; cibarial arch complete. Pigment patch indistinct. Palpal formula 1:4:2:3:5, lengths of segments as follows: P1 - 0.024; P2 - 0.078; P3- 0.102; P4 0.066 ; P5 - 0.216. Antennal ascoids simple, extending past boundary of flagellomere. Length of flagellomeres as follows: I - 0.132; II - 0.083; III - 0.087; IV - 0.087. Pleurae slightly paler than mesonotum and rest of body, with 8 upper and 4 lower episternal setae. Wings narrow, 1.275 long and 0.337 wide. Length of wing vein sections as follows: alpha - 0.225 ; beta - 0.157 ; gamma 0.217 ; delta -0.060 . Legths of leg segments as follows: prothoracic femur 0.525 , tibia 0.540 , basitarsus 0.292 ; mesothoracic femur 0.532 , tibia 0.645 , basitarsus 0.344 ; metathoracic femur 0.577 , tibia 0.825 , basitarsus 0.390 . Genitalia dark as mesonotum, consisting of wide coxide 0.228 long, from which a central circular tuft of 20 setae arises. Style 0.138 long, bearing a subterminal seta and four strong spines, two on median third, one at apex and one subapical, mounted on small tubercle. Paramere chitinous, somewhat setiferous and simple with indentation on tip giving a slightly "duck-billed" appearance. Aedeagus elongate and triangular. Genital pump 0.138 long, filaments smooths, 0.357 long or, 2.6 times length of pump. Tips of filaments acute. Lateral lobe 0.282 long, slightly recurved, with two spatulate setae at distal end. 

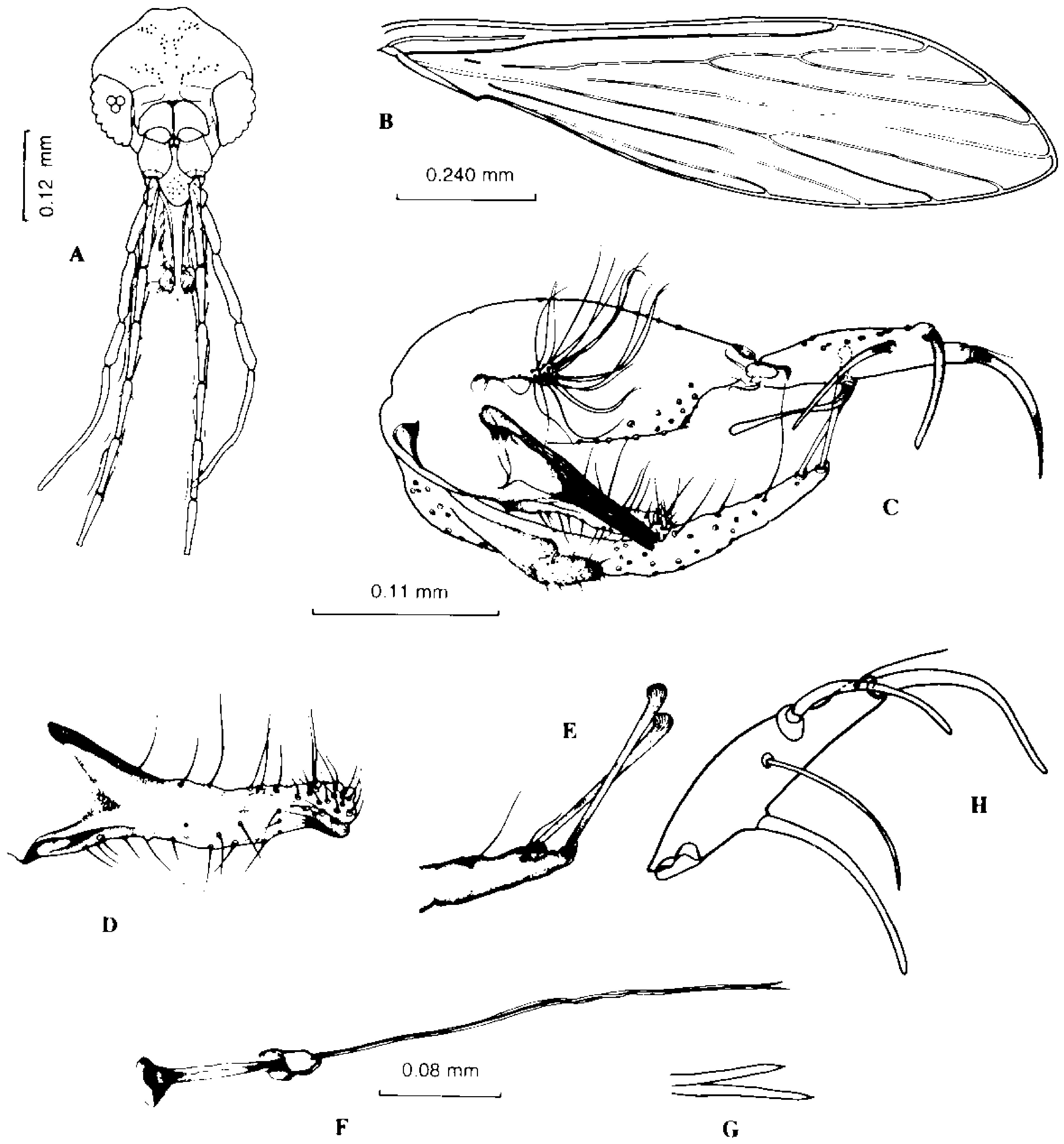

Lutzomyia sipani sp.n., male. A: head. B: wing. C: genitalia. D: paramere. E: spatulate setae. F: genital pump and filaments. G: tip of genital filaments. H: $L u$. bourrouli, subterminal setae (according to Galati).

Erymology: this species is named after the late entomologist and epidemiologist Felipe Sipan Tolay (1920-1991), in honor of his dedicated contribution on the field of tropical medicine in Peru.

Type locality: the holotype (NAMRID access No. 1031) and paratypes (Nos 1036 and 1037) were collected at San Antonio, Maynas, Loreto Department $\left(73^{\circ} 20^{\prime} \mathrm{N}: 03^{\circ} 26^{\circ} \mathrm{W}\right)$ at an altitude of $450 \mathrm{~m}$ above the sea level. San Antonio is located on the left bank of the Momon river, a tributary of the Rio Nanay. Specimens were collected on 21 November 1991 using a CDC light trap baited with dry ice hung in a chicken coop and by direct aspiration from the walls of a pig pen. The holotype will be deposited in the Javier Prado Museum of Natural History, Lima. Paratype 1036 will be donated to the Faculty of Public Health, Department of Epidemiology of the University of São Paulo, Brazil. Paratype 1037 will remain in the NAMRID collection. 
Discussion: we place L. sipani in the subgenus Evandromyia, series infraspinosa based on the following characteristics: presence of apical spatulate setae on the dorsum of the lateral lobe; tuft of persistent setae arising from a circular base on the coxite; and presence of four strong spines and a subterminal seta on the style. The new species appears to be closest to L. bourrouli (Barretto \& Coutinho 1941), which also has a simple paramere and four strong spines but which has three, not two, spatulate setae on the lateral lobe. $L$. pinottii (Damasceno \& Arouk 1956) resembles $L$. sipani in having a subterminal seta but bears four spatulate setae on the lateral lob. The parameres of the two species are also different, that of $L$. pinottii being blunt rather than "duckbilled". L. cerqueirai (Causey \& Damasceno 1945), of which several males were present in the same collections as the new species, has three spatulate setae on the lateral lobe, a subterminal seta and four strong spines on the style, but the latter are located more apically than L. sipani, and the paramere is birfurcate rather than simple. The present report extends the known range of the species, which had previously been recorded from the Columbian Andes (Young \& Morales 1987) and Brazil (Martins et al. 1978, Ryan 1986).

No females of $L$. sipani were collected but these presumably resemble those of $L$. bourrouli and $L$. pinottii. Ryan et al. (1987) reported a natural trypanosome infection in females of the latter species collected in the State of Para, Brazil, but the members of the subgenus Evandromyia are not known to be of medical significance. The males of $L$ sipani captured in the present study may have been seeking females attracted to chickens, but little information is available on the host preferences of this group. C Ferro (cited in Young \& Morales 1987) noted that $L$. cerqueirai females were apparently attracted to caged hamsters placed in secondary forest in Colombia.

\section{ACKNOWLEDGEMENTS}

To Eunice Aparecida Bianchi Galati, M.D., School of Public Health, University of Sào Paulo, Brazil, for her valuable suggestions and review of the manuscript, as well as for supplying drawings of $L$. pinottii and $L$. bourrouli. To Roberto Falcón for assistance with field collections.

\section{REFERENCES}

Barreto M, Coutinho J 1941. Contribuiçào ao conhecimento dos flebótomos de Sảo Paulo. VI. Descriçào de duas novas espécies (Diptera, Psychodidae). Papéis Avulsos Dept Zool Säo Paulo 1: 223-226

Causey OR, Damasceno RG 1945. Estudo sobre Flebotomus no Vale Amazónico. Parte VI. Descriçào de $F$. cerqueirai, $F$. dreisbachi, $F$. meirai \& $F$. ferreirai (Diptera-Psychodidae). Mem Inst Oswaldo Cruz 42: 645-660.

Damasceno R, Arouck R 1956. Estudos sobre flebótomos no Vale Amazónico. Parte III. Descriçào de $F$. pinotii, $F$. scaffi e F. nevesi (DipteraPsychodidae). Documento mimeografado apresentado no XIII Congresso de Higiene, Belém, PA, Brazil.

I lanos B 1983. Los flebótonnos del Perí y su distribuición geografica (Diptera, Psychodidae, Phlebotominae). Rev Peru Entomol 1981, 24: 183-184.

Mangabeira O 1941. Contribuiçào ao estudo dos Flebotomus. Evandromyia n. subg. (Diptera: Psycloxdidae). Mem Inst Oswaldo Cruz 36: 215-233.

Martins AV, Falcāo AL, Silva JE 1964. Um novo flebótomo no Estado de Goias, Lutzomyia teralodes sp.n. (Diptera, Psychodidae). Rev Bras Biol 24: $321-324$

Martins AV, Williarns P, Falcào AL 1978. American sand flies (Dip tera: Psycodidae, Phlebotominae). Academia Brasileira de Ciências, Rio de Jateiro, RJ 195p.

Ryan L 1986. Flebótomos do Estado do Pará, Brasil (Diptera: Psychodidae, Phlebolominae). Doc. Técnico $n^{0}$ 1, Instituto Evandro Chagas, Fundaçào SESP, Belém, Brazil 154p.

Ryan L, Lainson R, Shaw JJ, Braga RR, Ishikawa EAY 1987. Leishmaniasis in Brazil. XXV. Sandfly vectors of Leishmania in Para State, Brazil. Med Vet Entomol 1: 383-395.

Young DG, Arias J 1977. Lutzomyia sand flies in the subgenus Evandromyia Mangabeira, with descriptions of a new species from Brazil (Diptera: Psychodidae). Acta Amazonica 7: 59-70.

Young DG, Duncan M 1993. Guide to the identification and geographic distribution of Lutzomyia sand flies in Mexico, the West Indies, Central and South America (Diptera: Psychodidae). $\mathrm{Mem}$ Amer Entomol Inst 54: (in press).

Young DG, Morales A 1987. New species and records of phlebotominae sand flies from Colombia (Diptera: Psychodidae). J Med Entomol 24: 651-665.

Young DG, Perez JE, Romero G 1985. New records of phlebotominae sand flies from Peru with a description of Lutzomyia oligodonta n.sp., from the Rimac Valley (Diptera: Psychodidae). Int J Entomol 27: 136-146. 